https://doi.org/10.48009/2_iis_2008_123-131

\title{
A FRAMEWORK FOR A GREEN PRODUCT LIFECYCLE MANAGEMENT SYSTEM
}

Amy J.C. Trappey, National Taipei University of Technology, Taiwan, trappey@ntut.edu.tw

Fataneh Taghaboni-Dutta, University of Michigan-Flint, fataneh@umflint.edu

Charles V. Trappey, National Chiao Tung University, Taiwan, trappey@faculty.nctu.edu.tw

\begin{abstract}
Product lifecycle management systems provide a platform for the management of data related to the creation and disposal of products. These systems assist the participants in the products' life cycle processes (manufacturers, suppliers, customers, and regulators) to use data efficiently for planning and control. However, most data collected do not resolve the environmental issues which arise when selling the products or arranging for the products to be replaced and/or disposed of. In this paper, An Integrated Green Parts Information Platform (IGPIP) framework is described. This system uses XML file transmission to improve the quality, cost and time-to market issues for green designs.
\end{abstract}

KEYWORDS: Product Lifecycle Management, Green Component, XML, Mapping Hub

\section{GREEN DESIGN}

In June of 1992, the United Nations held a conference on Environment and Development in Rio de Janeiro. The goal of this conference was to gather policy makers and arrive at a general consensus to limit pollution at its source which includes product inception and manufacture. Thus, the environmental scientists' task is no longer limited to the management of environmental pollution, but also to control, repair and effectively stop environmental pollution.

The U.S. Environmental Protection Agency [4] describes green engineering as the design, commercialization, and use of processes and products which are feasible and economical while minimizing (1) generation of pollution at the beginning and (2) the risk to human health and the environment. Green engineering embraces the concept that decisions to protect human health and the environment have the greatest impact and cost effectiveness when applied early in the design and development phase of a process or product.

Werner [10] defines green design, or design for the environment, as practices which yield products with minimal environmental impact. The environment is not only impacted by the use of resources to manufacture the product but also by its use by the consumer and finally its disassembly and

disposal. Green engineering is an approach which aims to control and reduce pollution by taking into account the impact of the products on the environment during the design phase [3].

The Environmentally Conscious Business Practice (ECBP) model is a valuable framework to use for evaluating and selecting green strategies. The ECBP model integrates several factors of enterprise decision making related to environment including: design for the environment, life cycle analysis, total quality environmental management, green supply chain management, and ISO 14000 environment management system requirements.

The environmental factors to be considered when designing green products spans the material, production, packaging, transportation, usage, waste management, and recovery - see Table 1 for detailed factors to be considered which are based on research presented in the literature [4], [6], [7], [9].

Table 1 Environment factors in product life cycle

\begin{tabular}{|c|c|}
\hline $\begin{array}{l}\text { Product Life } \\
\text { Cycle }\end{array}$ & Factors to consider \\
\hline Material & $\begin{array}{l}\text { Reduce volume of raw material } \\
\text { Nature of raw material } \\
\text { Eliminate or } \\
\text { non-renewable usage } \\
\text { Eliminate and/or Reduce } \\
\text { hazardous raw material usage } \\
\text { Facilitate recovery, reuse, } \\
\text { recycling } \\
\text { Extraction and processing of raw } \\
\text { materials } \\
\text { Transport from supplier }\end{array}$ \\
\hline Production & $\begin{array}{l}\text { Optimize production technology } \\
\text { Eliminate/reduce emissions to air } \\
\text { Eliminate/reduce effluents } \\
\text { Minimizing the type of using } \\
\text { materials } \\
\text { Eliminate/reduce waste in } \\
\text { manufacturing process } \\
\text { Reduce energy usage }\end{array}$ \\
\hline
\end{tabular}




\begin{tabular}{|c|c|}
\hline $\begin{array}{l}\text { Package, } \\
\text { transportation }\end{array}$ & $\begin{array}{l}\text { Is transport necessary } \\
\text { Volume and nature of transport } \\
\text { Type of fuel usage } \\
\text { Eliminate/reduce emissions to air } \\
\text { Eliminate/reduce waste } \\
\text { Avoid to use hazardous package } \\
\text { Minimize the volume and weight } \\
\text { of package }\end{array}$ \\
\hline Use & $\begin{array}{l}\text { Eliminate/reduce } \\
\text { generation } \\
\text { Design for repair } \\
\text { Extend product life } \\
\text { Minimize the loss of tool } \\
\text { Minimize the noise } \\
\text { Eliminate/reduce emissions to air } \\
\text { Eliminate/reduce effluents } \\
\text { Reduce resources usage }\end{array}$ \\
\hline Waste, Recovery & $\begin{array}{l}\text { Minimize the volume and weight } \\
\text { of the waste } \\
\text { Maximize the recovery rate } \\
\text { Maximize the reuse and } \\
\text { recycling rate } \\
\text { Modular design for maximizing } \\
\text { upgradeability } \\
\text { Facilitate recovery } \\
\text { components for reuse } \\
\begin{array}{l}\text { Facilitate recovery } \\
\text { components for recycling and } \\
\text { disposal }\end{array}\end{array}$ \\
\hline
\end{tabular}

\section{PRODUCT DATA MANAGEMENT (PDM)}

Managing the product data is a complicated challenge for the manufacturing industry, which needs to frequently design or re-design and manufacture products to reflect the changing market needs. The related information includes: the component list, the classifying rules, multi-layered bill-of-materials (BOM), all engineering files (CAD/CAE/CAM), electronic documents and other information related to the product life cycle. Product Data Management (PDM) system is used to organize, save and control all information related to the product design, manufacturing and its life cycle management [1]. Trappey, et al. [9] defines PDM as a system which helps design teams manage product information of products electronically. One of the important characteristics of PDM should be its ability to integrate, exchange, and manage all product-related data and procedures across heterogeneous platforms and organizational boundaries. The product data needed to integrate the relevant information among the prime manufacturers, subcontractors, suppliers, and other partners is shown in Figure 1.

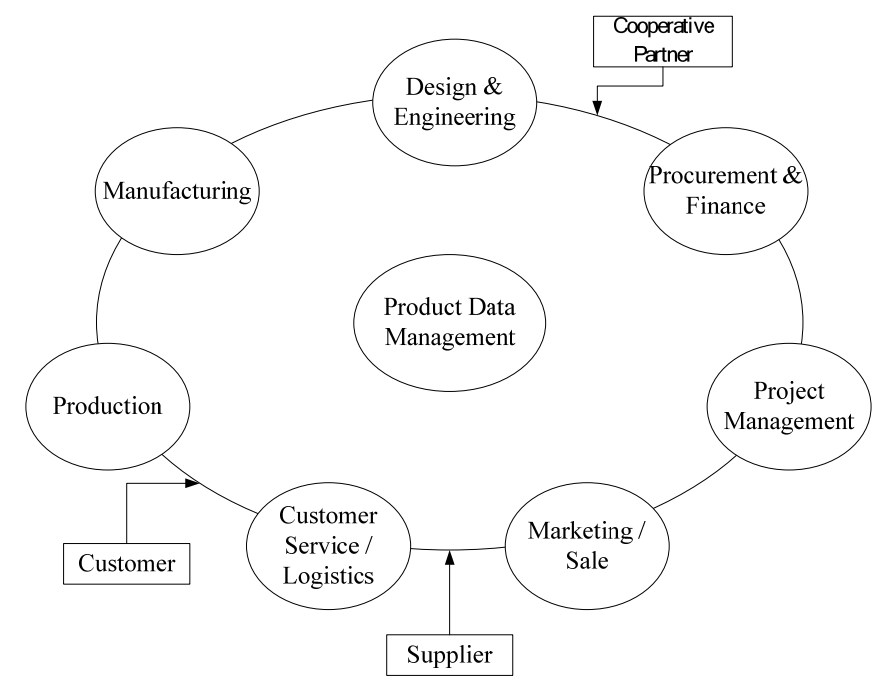

Figure 1. PDM Structure (Trappey, et al., 2001)

Product lifecycle management (PLM) further expands the scope of PDM to include a strategic business approach, support for the extended enterprise, to integrate people, processes, business systems, and information [1].

\section{INTEGRATED GREEN PARTS INFORMATION PLATFORM (IGPIP)}

Some chemicals and materials cause significant damage to the environment and many regulators restrict their usage. For example, the RoHS [2] issued by European Union restricts the use of cadmium, mercury, hexavalent chromium, polybrominated biphenyl (PBB) and polybrominated biphenyl ether (PBDE) flame retardants in products for the European market.

The data management is a very complex issue since manufacturers routinely manage thousands of products. Thus, there is a need for a system which facilitates the upload and management of product information without too much human interaction. One solution is to use XML files to upload the manufacturer's products information. The XML file is generated by the enterprise system or component information system and typically conforms to the manufacturer's schema definition. In this paper an Integrated Green Parts Information Platform (IGPIP) is proposed which will enable companies to share and manage product information, including environmental related (green) data, among multiple users in the supply chain network. This system can work across differing platforms since the users will send and receive the green parts information effectively via an XML-based exchange module. 
First each manufacturer transmits product information via XML files, subsequently these files are translated into a uniform schema for distribution across different platforms. The users of the system can map their own schema to the schema of the system and generate eXensible Stylesheet Language Transformations (XSLT) files according to user defined rules.

When green products are designed and developed, a large quantity of parts information is provided. The availability of green parts information would allow designers to effectively select substitutes and alternatives that can substantially lower the cost of development and production of environmentally friendly products. Most companies use an enterprise management system or a component information system which contain parts specifications. The products' designers use these systems to locate parts that can be included in new products. If the designers cannot find suitable parts, then they reference vendors' databases. When a green part is located, it is added to the enterprise or component information system.

\section{IGPIP SYSTEM ARCHITECTURE}

IGPIP is built around three layers: the user interface layer, the functions layer, and the data layer - see figure 2. The user interface provides a web-based interface for executing system functions. The functions layer includes the XML schema exchange module which automatically generates the eXensible Stylesheet Language Transformations (XSLTs) files allowing two parties to exchange data across platforms. Finally, the data layer contains the green part database and the XSLT database. The green part database stores information related to the green part. The XSLT database holds data which has been parsed from the XML files, information from test reports, and the schema mapping rules for each company.

\section{(insert Figure 2 here)}

The function layer contains four major modules: Member Management Module, XML Schema Hub Module, Search and Survey Module, and Green Part (GP) Data Management Module. Table 2 shows the relationship between the modules, their functions, and the members.
Table 2. IGPIP function list

\begin{tabular}{|c|c|c|}
\hline Module Name & $\begin{array}{l}\text { Function } \\
\text { Name }\end{array}$ & $\begin{array}{l}\text { Request } \\
\text { Member Level }\end{array}$ \\
\hline \multirow{5}{*}{$\begin{array}{l}\text { Member } \\
\text { Management } \\
\text { Module }\end{array}$} & Add member & Administrator \\
\hline & $\begin{array}{l}\text { Member } \\
\text { management }\end{array}$ & Administrator \\
\hline & $\begin{array}{l}\text { Maintain } \\
\text { member data }\end{array}$ & $\begin{array}{l}\text { General } \\
\text { member }\end{array}$ \\
\hline & Log-in & $\begin{array}{l}\text { General } \\
\text { member }\end{array}$ \\
\hline & Log-out & $\begin{array}{l}\text { General } \\
\text { member }\end{array}$ \\
\hline \multirow{4}{*}{ XML Hub } & $\begin{array}{ll}\text { XML } & \text { file } \\
\text { upload } & \end{array}$ & $\begin{array}{l}\text { Supplier, OEM } \\
\text { member }\end{array}$ \\
\hline & $\begin{array}{ll}\begin{array}{l}\text { XML } \\
\text { download }\end{array} & \text { file } \\
\end{array}$ & $\begin{array}{l}\text { Supplier, OEM } \\
\text { member }\end{array}$ \\
\hline & $\begin{array}{l}\text { Registry } \\
\text { schema }\end{array}$ & $\begin{array}{l}\text { Supplier, OEM } \\
\text { member }\end{array}$ \\
\hline & $\begin{array}{l}\text { Schema } \\
\text { mapping } \\
\text { service }\end{array}$ & $\begin{array}{l}\text { Supplier, OEM } \\
\text { member }\end{array}$ \\
\hline \multirow{2}{*}{$\begin{array}{l}\text { Search and } \\
\text { Survey Module }\end{array}$} & $\begin{array}{l}\text { Green part } \\
\text { search }\end{array}$ & $\begin{array}{l}\text { General } \\
\text { member }\end{array}$ \\
\hline & $\begin{array}{ll}\begin{array}{l}\text { Green } \\
\text { survey }\end{array} & \text { part }\end{array}$ & $\begin{array}{l}\text { General } \\
\text { member }\end{array}$ \\
\hline \multirow{5}{*}{$\begin{array}{l}\text { Green Part Data } \\
\text { Management } \\
\text { Module }\end{array}$} & Add green part & $\begin{array}{l}\text { Supplier, OEM } \\
\text { member }\end{array}$ \\
\hline & $\begin{array}{l}\text { Maintain green } \\
\text { part }\end{array}$ & $\begin{array}{l}\text { Supplier, OEM } \\
\text { member }\end{array}$ \\
\hline & $\begin{array}{l}\text { Delete green } \\
\text { part }\end{array}$ & $\begin{array}{l}\text { Supplier, OEM } \\
\text { member }\end{array}$ \\
\hline & $\begin{array}{ll}\text { Test } & \text { report } \\
\text { upload } & \\
\end{array}$ & $\begin{array}{l}\text { Supplier, OEM } \\
\text { member }\end{array}$ \\
\hline & $\begin{array}{l}\text { Test report } \\
\text { download }\end{array}$ & $\begin{array}{l}\text { General } \\
\text { member }\end{array}$ \\
\hline
\end{tabular}

\section{IGPIP PROCESS FLOW}

Figure 3 shows the main process flow. First, the user enters the system homepage and activates the login interface. The system reads the account number and password and ascertains the user's appropriate level of authority. The user then can executes the system appropriate for their role and level of authority.

\section{(insert Fiure 3 here)}

Four different role classifications: general members, supplier members, OEM members, and administrators; determines the authority of the users. Table 3 summarizes the authority levels of the different roles. The general members use the Search and Survey Module to access green part data from the information platform. Suppliers have the same authority as the manufacturers, and as the primary users of the system, they also have authority to execute the schema mapping service and use the 
XSLTs to upload and download the XML green parts files. Using the platform, suppliers can upload their green parts to the system and manufacturers can download part data, each using their own schema. The administrators maintain the member data and the system.

Table 3. Authority levels of different users

\begin{tabular}{|l|l|}
\hline Roles & Limit of Authority \\
\hline $\begin{array}{l}\text { General } \\
\text { Member }\end{array}$ & $\begin{array}{l}\text { Modifying member data, search } \\
\text { and survey green parts. }\end{array}$ \\
\hline $\begin{array}{l}\text { Suppliers and } \\
\text { manufacturers }\end{array}$ & $\begin{array}{l}\text { Manage information related to } \\
\text { green parts, execute the XML } \\
\text { schema mapping service. }\end{array}$ \\
\hline Administrator & Managing member data \\
\hline
\end{tabular}

The user interface with IGPIP platform starts with a registration/login page where the user fill in the blanks with suitable data which are then sent to the system administrator. Figure 4 is a schematic of the process for Supplier/Manufacturer registration process.

(insert Figure 4 here)

The Green Part Data Management Module enables the suppliers to add green parts information and let others access their information. This function is limited to the suppliers. The suppliers upload their XML files from their own systems. The IGPIP then automatically translates the uploaded XML files and saves the green part information into the database. If a supplier cannot automatically generate an XML file for their green parts, then they can add parts information using the web-based interface. The Green Part Data Management Module and the XML hub Module facilities all these transactions seamlessly.

Test Report function, performed within the Green Part Data Management Module, enables the suppliers to upload test reports for green parts. These test reports are generated by the verification organizations which verify that the green parts listed, indeed, follow the environmental regulations.

The Search and Survey Module provides a search interface for the manufacturers. OEM members log in, enter the search interface, and input the supplier's name, green part's name and their restrictions. The system then lists all green parts that fit the search see Figure 5 . This module will significantly reduce the time and effort required to find suitable green parts early in the design stage.

(insert Figure 5 here)
For any platform to be useful it must facilitate the exchange of green part information with ease and minimum human intervention. To accommodate a seamless data sharing platform, the IGPIP has been designed to provide the capability of automatically translating different XML schemas. The Schema Mapping Function, a function within the XML Hub, enables the members to define the rules for translating schemas.

The XML Schema Mapping service is to be used by suppliers and manufacturer; members log into the system and then access the Schema Mapping interface. The green part XML schema is generated using the international product material composition declaration standard, RosettaNet 2A13. The green part XML schema uses this intermediary XML standard to simplify translation and exchange. From the Schema Mapping Interface, the users upload an XML schema and the system parses the document and displays a structure tree. Members check the rules and save the XSLT document and generate the XSLT files.

Figure 6 shows the architecture of the XML Schema Translation Hub. The schema includes manufacturing process information, part information (such as weight, subparts, material, product identification, etc.) and suppliers' information. The schema combines the information of the manufacturing processes of the green parts and the information for related test reports.

(insert Figure 6 here)

The XML Schema Translation Hub provides members with an XML mapping service, the mapping interface is a web-based mapping tool which allows the users to finish their mapping on the web. The interface provides the rules for mapping, as well as allowing the users to define their own rules. After the relations between schema files are linked and defined, mapping services generate two XSLTs: company-to-hub XSLT and hub-to-company XSLT. These two hubs execute the translations based on the generated XSLTs. The architecture of the mapping interface is shown in Figure 7.

\section{(insert Figure 7 here)}

As shown in table 4, there are three major tasks performed by the Mapping Service. As the first step, the suppliers register their green parts XML schemas. As members request mapping services, the system automatically loads the source and the target XML schema into the Schema Parser. The Schema Parser performs the analysis on the definition inside the schema that regulates the content and structure 
shown in XML documents. The Schema Parser records the properties of the tags defined in schema documents for future reference; these properties include: element type, name, data type, name space, occurrence, default value, fixed value, limitation and description. First the Schema Parser records the tags data, and then the tree constructor uses the data to build a tree for representing the XML document. The tree helps members understand the structure of XML documents and enables the analysis of the element details. After mapping is completed, the schemas are sent to an XSLT generator which generates XSLT files and stores them in the database.

Table 4. The Mapping Service functions

\begin{tabular}{|l|l|}
\hline Functions & Descriptions \\
\hline $\begin{array}{l}\text { Schema } \\
\text { parser }\end{array}$ & $\begin{array}{l}\text { Reads schemata definitions, structures a } \\
\text { presentation, and then sends it to Mapper. }\end{array}$ \\
\hline Mapper & $\begin{array}{l}\text { Provides several methods for users to map } \\
\text { their business documents. Mapper stores } \\
\text { the mapping definitions created by the users, } \\
\text { and finally sends it to XSLT generator. }\end{array}$ \\
\hline $\begin{array}{l}\text { XSLT } \\
\text { generator }\end{array}$ & $\begin{array}{l}\text { Generates XSLT documents following the } \\
\text { completion of mapping definitions. }\end{array}$ \\
\hline
\end{tabular}

\section{CONCLUSION}

This paper presents a framework for an information exchange platform which will enable manufacturers and designer to increase the usage of green parts and/or parts to satisfy the requirements for environmentally regulated products with as minimal an effort as possible. To achieve this goal and to be able to include all members of the supply chain, who will have their own enterprise resource planning systems, the platform is built on an XML-based hub with a web-based interface. The XML Hub is based on the RosettaNet 2A13 standard and it enables suppliers and manufacturers to translate their part data for efficient Internet-based data exchange. The proposed platform provides the ability to integrate, exchange, and manage all product-related data and procedures across heterogeneous platforms and organizational boundaries. The proposed design of this platform eliminates the need for members to use different data standards than what is used internally within each company. The clear advantage of such data exchange system is in its ability to accommodate differing resource planning platforms. This platform will allow companies to reduce overall product development cost through reduced lead time in product design and manufacture as well as reduced need for human resources. Additionally, providing a public information platform better enables members to find and select green parts for manufacturing.
Environmental laws and public opinion will have a great impact on how companies have to show that their products are being designed and manufactured with minimal negative environmental impact. We believe that the system described in this paper will provide a tool which will enable manufacturing companies to attain this objective quickly and with minimal effort and/or investment. A prototype of the system described here is being tested on several industrial cases, results of which will be provided in future research publications.

\section{ACKNOWLEDGEMENT}

This paper is partially supported by the National Science Council grant. Yu-Xing Huang, a graduate student at National Tsing Hua University, worked on the Taiwan Electrical Equipment Manufacturer's Association (TEEMA) prototype implementation.

\section{REFERENCE}

1. CIMdata, Inc., "Product Data Management: The Definition, An Introduction to Concepts, Benefits, and Terminology, September 2, 1997”

2. http://www.rohs.gov.uk/, accessed March, $2008 . \quad$ Also see http://www.rohs.gov.uk/Docs/NWML\%20Y ear\%20One\%20Report\%20-\%20November \%202007.pdf

3. SME, "CASA/SME Blue Book: Green Manufacturing”, Jan 01, 1996

4.

Protection Agency $\quad$ website
http://www.epa.gov/opptintr/greenengineeri ng/whats_ge.html

5. Coggins, Chris ; "Waste prevention - an issue of shared responsibility for UK producers and consumers: policy options and measurement”; Resources, Conservation and Recycling 32, 2001, pp.181-190

6. Fullerton, Don and Wenbo Wu; "Policies for Green Design”; Journal of Environmental Economics and Management 36, 1998, pp.131-148

7. Maxwell, D.; van der Vorst, R; "Developing sustainable products and services”; Journal of Cleaner Production Volume: 11, Issue: 8, December, 2003, pp. 883-895

8. Sarkis, Joseph; Evaluating environmentally conscious business practices; European Journal of Operational Research Volume: 107, Issue: 1, May 16, 1998, pp. 159-174. 
9. Trappey, et al, Product Data Management, Taiwan: Chan-Hai Publishing, 2001 ISBN957-2079-34-4

10. Werner J. Glantschnig: Green Design: A Review of Issues and Challenges: IEEE, pp. 74-78, 1993 


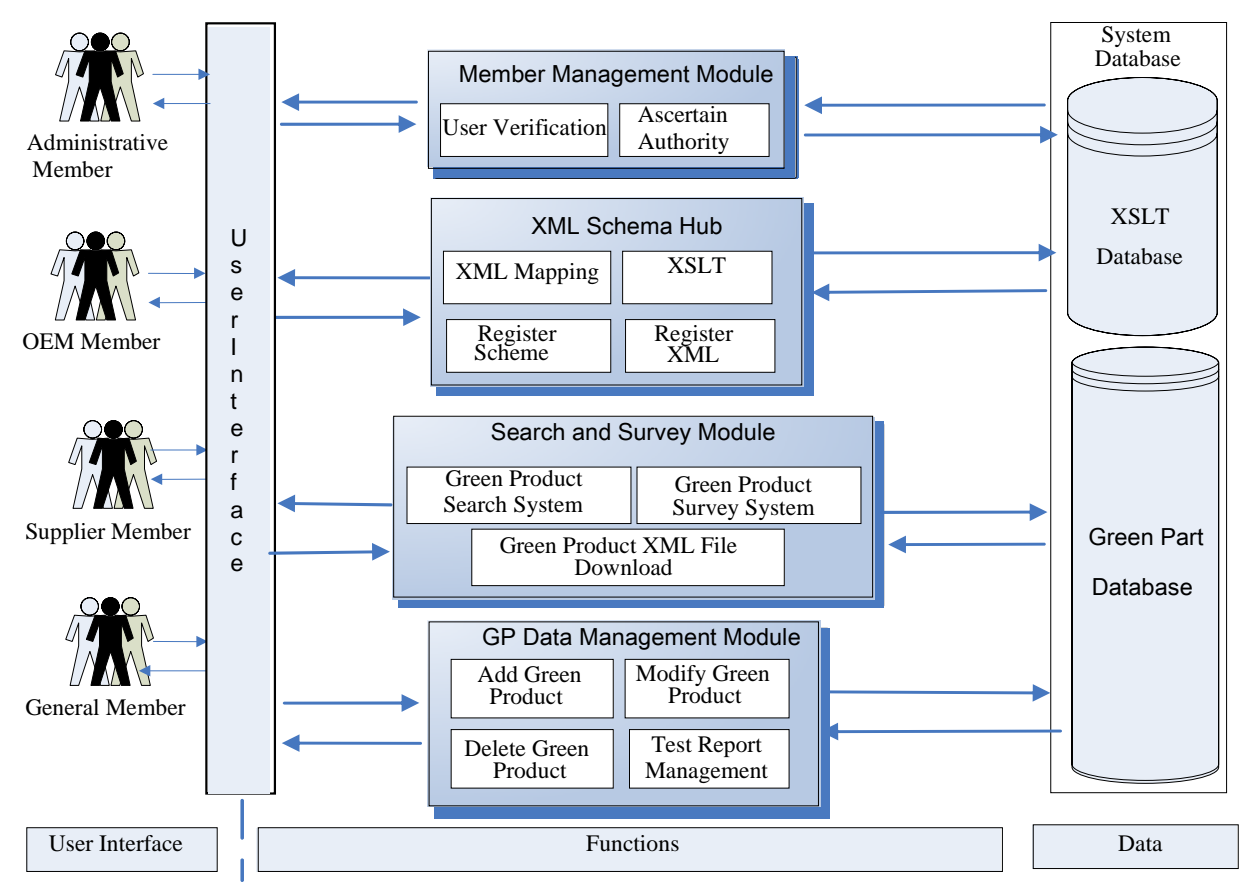

Figure 2. The three layers of IGPIP system

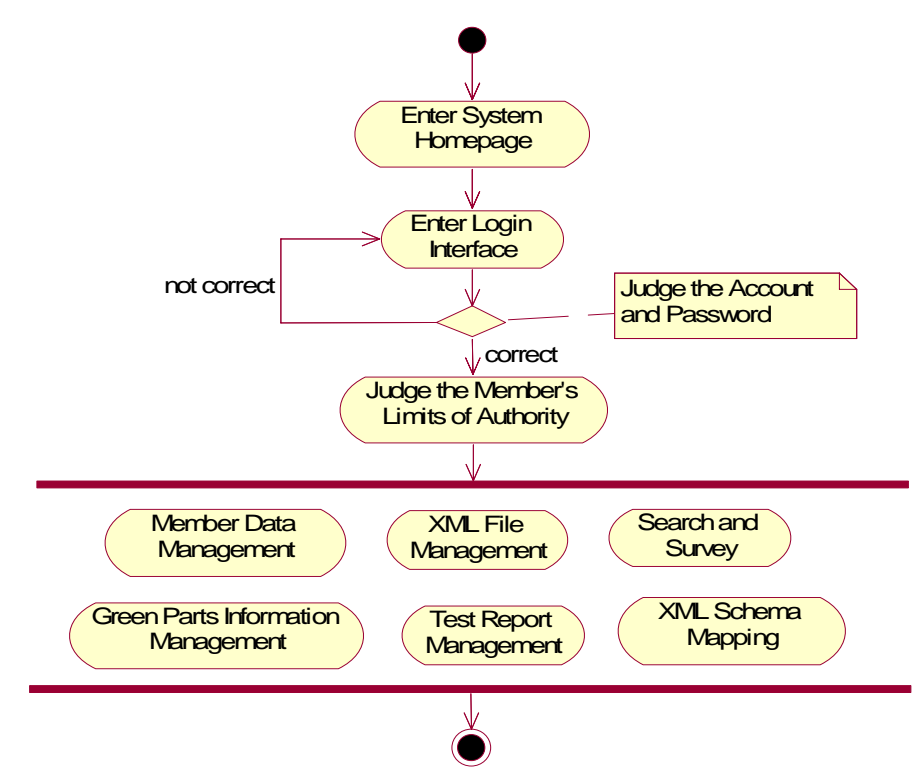

Figure 3. The IGPIP main process flow 


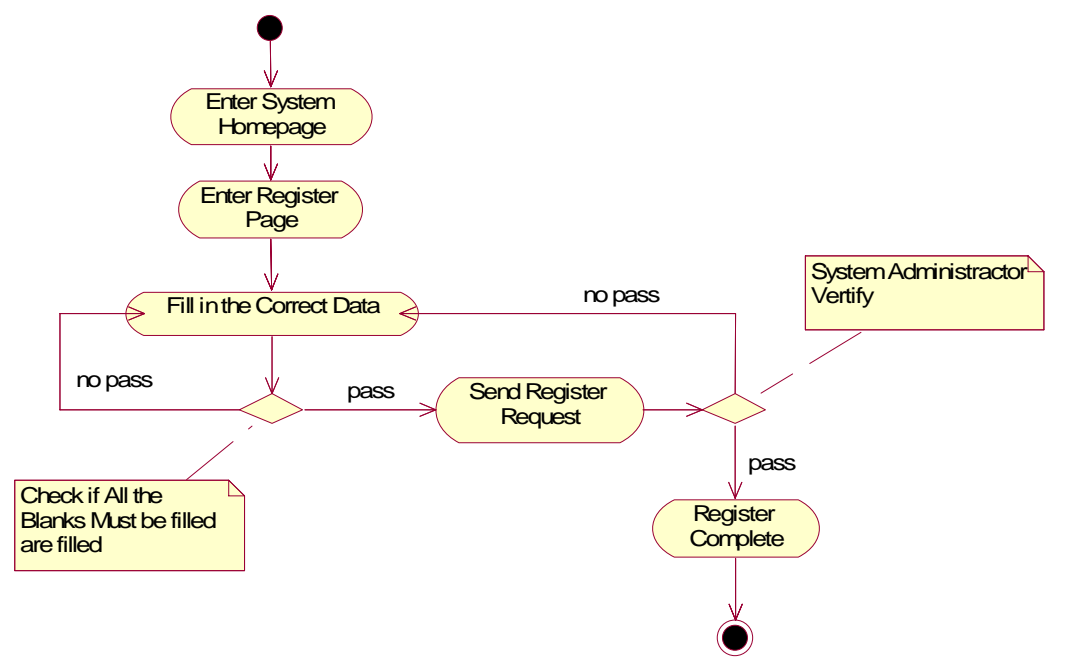

Figure 4. Manufacturer and supplier registration

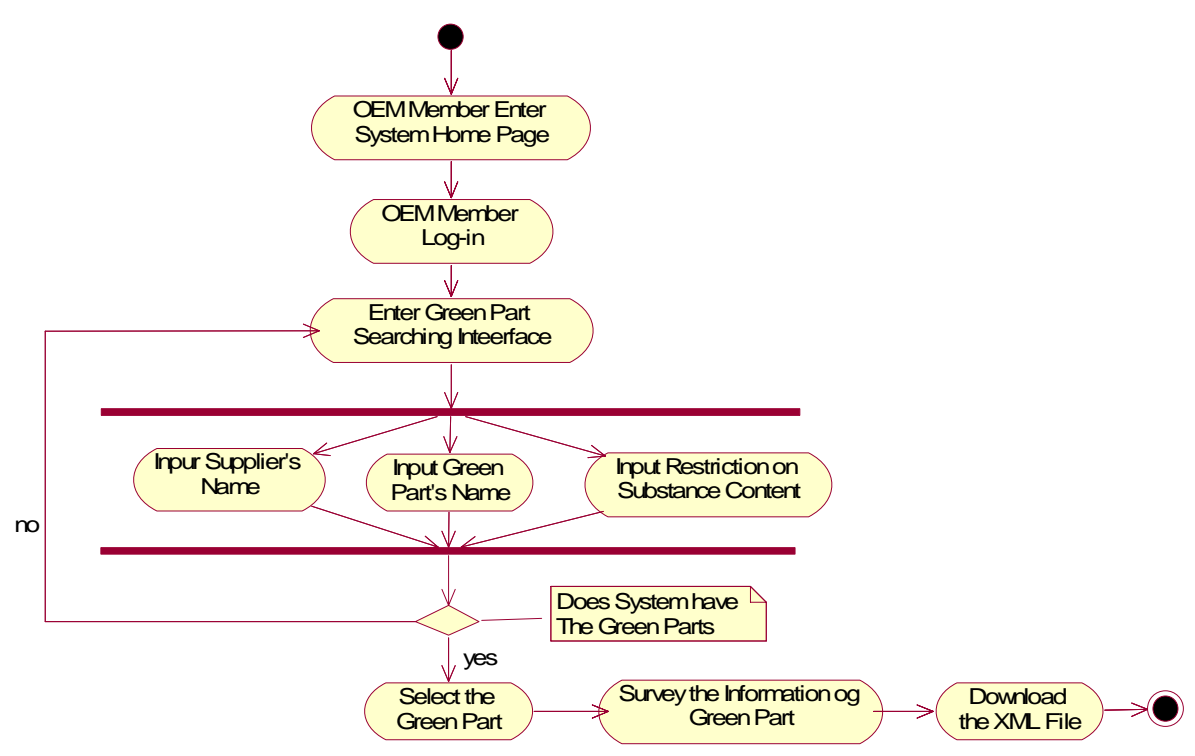

Figure 5. Search and survey process flow activity diagram 


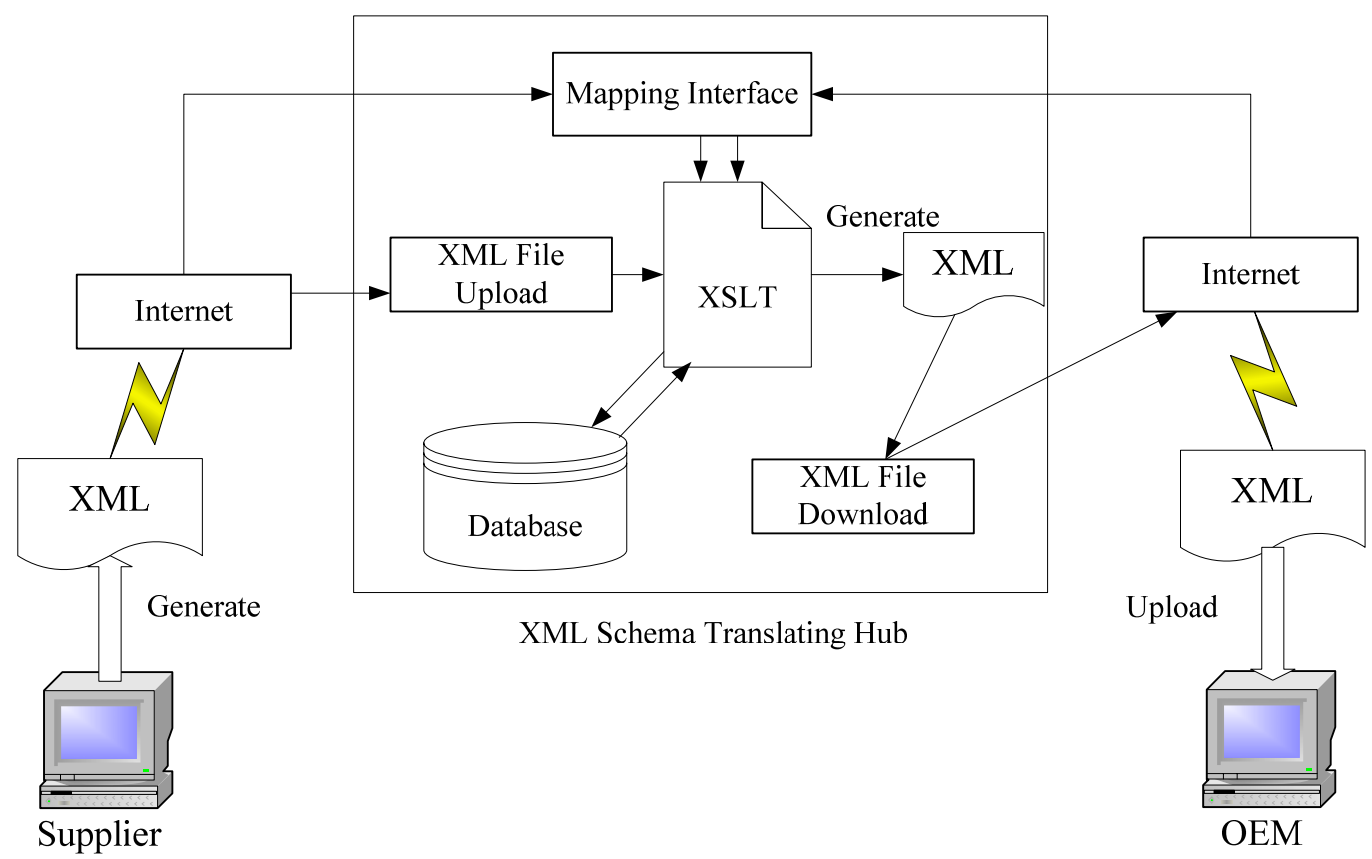

Figure 6. Architecture of XML schema translation hub

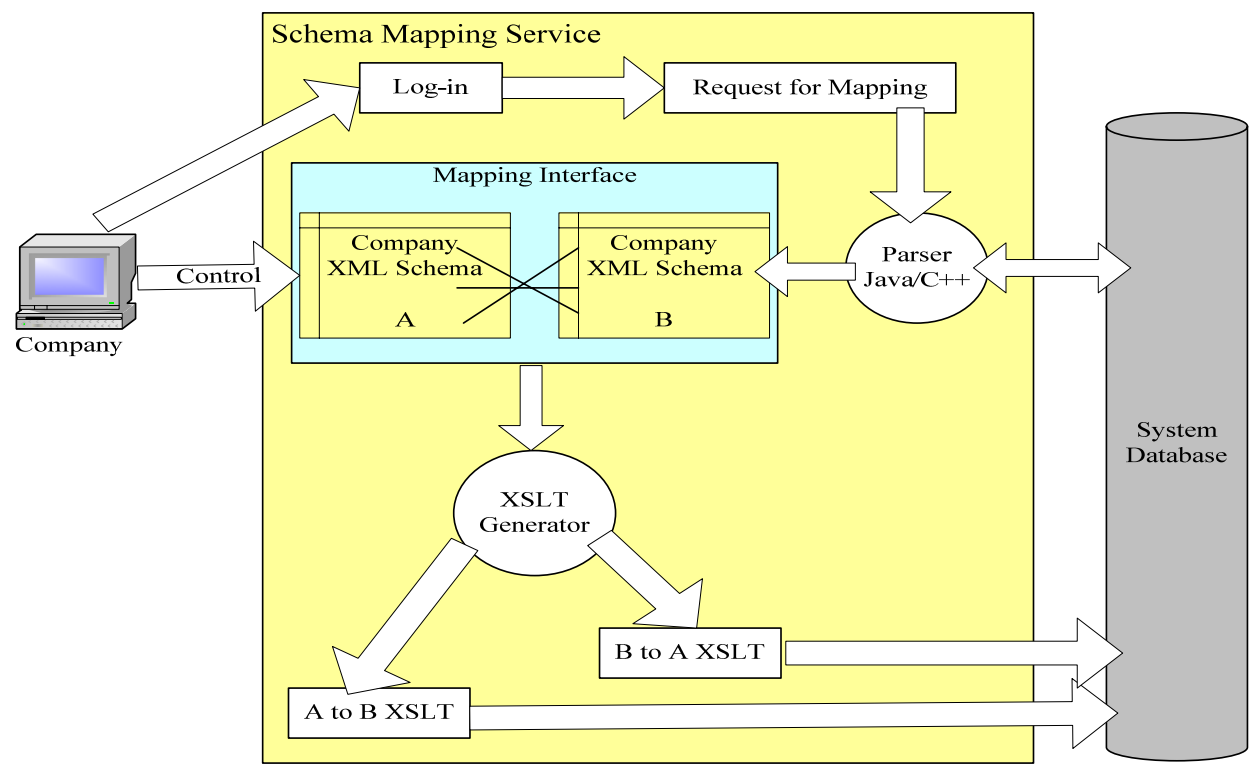

Figure 7. The mapping services architecture 